\title{
Estradiol/progesterone implants increase food intake, reduce hyperglycemia and increase insulin resistance in endotoxic steers
}

\author{
C D McMahon, T H Elsasser², D R Gunter, L G Sanders ${ }^{1}$, \\ B P Steele and J L Sartin
} Departments of Anatomy, Physiology and Pharmacology, ${ }^{1}$ Discrete and Statistical Sciences, Auburn University, Auburn, Alabama 36849, USA and
${ }^{2}$ US Department of Agriculture, Agricultural Research Service, Growth Biology Laboratory, Beltsville, Maryland 20705, USA
(Requests for offprints should be addressed to J L Sartin, Department of Anatomy, Physiology and Pharmacology, College of Veterinary Medicine,
Auburn University, Auburn, Alabama 36849-5520, USA)

\begin{abstract}
High doses of lipopolysaccharide (LPS) induce transient hyperglycemia, then chronic hypoglycemia and increased insulin resistance. In addition, appetite is reduced, while body temperature and concentrations of cortisol and tumor necrosis factor alpha (TNF $\alpha$ ) are elevated. Furthermore, concentrations of GH and IGF-I are reduced in cattle. The objectives of this study were to determine whether a gonadal steroid implant $(20 \mathrm{mg}$ estrogen and $200 \mathrm{mg}$ progesterone) given to endotoxemic steers would: (1) reduce hyperglycemia, reduce hypoglycemia, reduce insulin resistance, (2) reduce changes in concentrations of GH and IGF-I, (3) reduce inappetence and reduce concentrations of blood urea nitrogen (BUN) and nonesterified fatty acids (NEFA), and (4) reduce fever and concentrations of TNF $\alpha$ and cortisol. Holstein steers were assigned within a $2 \times 2$ factorial arrangement of treatments as follows ( $n=5$ per group): C/C, no steroid and vehicle; $\mathrm{S} / \mathrm{C}$, steroid and vehicle; C/E, no steroid and LPS $(1 \mu \mathrm{g} / \mathrm{kg}$ body weight (BW), i.v.); S/E, steroid and endotoxin. Steroid implants were given at 20 weeks of age (day 0 ) and serial blood samples (15 min) were collected on day 14 for $8 \mathrm{~h}$, with vehicle or LPS injected after $2 \mathrm{~h}$. Intravenous glucose tolerance tests $(100 \mathrm{mg} / \mathrm{kg} \mathrm{BW})$ were carried out at $6 \mathrm{~h}$ and $24 \mathrm{~h}$. Hyperglycemia was $67 \%$ lower $(P<0.05)$ in S/E- compared with C/E-treated steers between 30 and $150 \mathrm{~min}$ after i.v. injection of LPS.
\end{abstract}

Hypoglycemia developed after $4 \mathrm{~h}$ and insulin resistance was greater in S/E- compared with $\mathrm{C} / \mathrm{E}$-treated steers $(P<0 \cdot 05)$ at 6 and $24 \mathrm{~h}$. Concentrations of IGF-I were restored earlier in steroid-treated steers than in controls. Concentrations of GH were not affected by steroids, but increased $1 \mathrm{~h}$ after injection of LPS, then were reduced for $2 \mathrm{~h}$. Appetite was greater $(P<0 \cdot 05)$ in S/E- $(2 \cdot 1 \% \mathrm{BW})$ compared with $\mathrm{C} / \mathrm{E}$-treated steers $(1 \cdot 1 \% \mathrm{BW})$ (pooled S.E.M. $=0 \cdot 3)$. Concentrations of NEFA increased after injecting LPS, but concentrations were lower $(P<0 \cdot 05)$ in S/E- compared with C/E-treated steers. LPS did not affect concentrations of BUN, but concentrations were lower in steroid-treated steers. Steroids did not affect body temperature or concentrations of TNF $\alpha$ and cortisol. In summary, gonadal steroids reduce hyperglycemia, reduce inappetence and tissue wasting, but increase insulin resistance. Furthermore, concentrations of IGF-I are restored earlier in steroid-treated than in non-steroid-treated steers injected with LPS. It is concluded that gonadal steroids reduce severity of some endocrine and metabolic parameters associated with endotoxemia. However, it is unlikely that gonadal steroids acted via anti-inflammatory and immunosuppressive actions of glucocorticoids or through reducing concentrations of cytokines.

Journal of Endocrinology (1998) 159, 469-478

\section{Introduction}

Administration of lipopolysaccharide (LPS), a structural component in the outer cell wall of Gram-negative bacteria, stimulates an immune response in mammalian hosts which leads to reduced appetite, altered metabolism and a reduced growth rate or loss of body weight (Coleman et al. 1993, Elsasser et al. 1995, Heath et al. 1997). Concentrations of growth hormone (GH) and insulin-like growth factor-I (IGF-I) are reduced in cattle after an injection of LPS (Elsasser et al. 1995). Further- more, glucose homeostasis is severely disrupted; low doses of LPS induce hyperglycemia between 1 to $3 \mathrm{~h}$, while higher doses of LPS induce chronic hypoglycemia, which develops after initial hyperglycemia and may persist for days (Lang et al. 1985, Giri et al. 1990, Elsasser et al. 1996). In addition, animals become insulin resistant, which, coupled with hypoglycemia, can be fatal because insufficient glucose is available for basal tissue requirements (Cryer 1992).

A number of studies have suggested that anabolic agents assist recovery from catabolic states (Clemmons et al. 1992, 
Byrne et al. 1993, Elsasser et al. 1994, Zhao \& Donovan 1995, Heath et al. 1997). In addition, gonadal steroid implants improve growth rates, enhance accretion of lean tissue and improve the conversion efficiency of feed in healthy steers (Unruh 1986, Breier et al. 1988, Enright et al. 1990) and this may be beneficial during catabolic disease. During infection, gonadal steroids are immunomodulatory, but their role in host defense is not well understood; actions range from increased severity of infection to enhanced recovery from infection (Grossman 1984, 1985, 1994). However, subcutaneous implants containing estradiol $\left(\mathrm{E}_{2}\right)$ and progesterone $\left(\mathrm{P}_{4}\right)$ reduce severity and enhance recovery from coccidiosis in steers (Heath et al. 1997). In that study, implanted steers ate more, did not lose weight and had a shorter duration of fever compared with infected, but non-implanted steers and there was an increased percentage of lymphocytes expressing CD4 antigens. Therefore, gonadal steroids may provide protection against infection and disease in addition to their actions on growth.

The hypothesis of the present study is that steroid implants would reduce the severity of endotoxemia in steers injected i.v. with a high dose of LPS. The objectives of this study were to determine whether $\mathrm{E}_{2} / \mathrm{P}_{4}$ implants would: first, reduce hyperglycemia, reduce hypoglycemia and reduce insulin resistance; secondly, reduce changes to concentrations of GH and IGF-I; thirdly, increase food intake and decrease mobilization of body tissues; and fourthly, reduce duration of fever and concentrations of tumor necrosis factor alpha (TNF $\alpha)$ and cortisol.

\section{Materials and Methods}

\section{Animals and maintenance}

Twenty Holstein steers obtained from the EV Smith Research Center (Shorter, AL, USA) were hand-reared indoors on whole milk. After weaning between 7 and 9 weeks of age, steers were released onto pasture and fed a concentrate feed which was calculated to provide weight gain of $1 \mathrm{~kg} /$ day $(14.9 \%$ dietary crude protein). Steers were free to graze and had access to water at all times.

\section{Experimental design}

Steers were allocated at random into one of four treatment groups ( $n=5$ per group) in a $2 \times 2$ factorial arrangement as follows: C/C, no steroid and vehicle (saline control); S/C, steroid (20 mg $\mathrm{E}_{2}$ and $200 \mathrm{mg} \mathrm{P}_{4}$, synovex-s, Fort Dodge, Des Moines, IO, USA) and vehicle; C/E, no steroid and given LPS i.v. $(1 \mu \mathrm{g} / \mathrm{kg}$ body weight $(\mathrm{BW})$ in saline $(0.1 \mathrm{mg} / \mathrm{ml})$ (E. coli serotype 055:B5, Sigma Chemical Corporation, St Louis, MO, USA)); S/E, steroid and LPS. At 20 weeks of age (day 0$), \mathrm{E}_{2} / \mathrm{P}_{4}$ was implanted in an ear of each $\mathrm{S} / \mathrm{C}$ and $\mathrm{S} / \mathrm{E}$ steer in accordance with manufac- turer's instructions. Mean BW was $168 \cdot 1 \pm 3.7 \mathrm{~kg}$ and average daily gain (ADG) was $790 \pm 277 \mathrm{~g} /$ day. Neither BW nor ADG significantly differed $(P>0.05)$ between groups. One week later (day 7), steers were moved from pasture to individual pens indoors. While indoors, steers were fed daily at $10 \%$ surplus to demand and had free access to feed. Feed intake was recorded daily and converted to dry matter intake (DMI) after correcting for moisture content by oven drying feed and refusal sub-samples at $50{ }^{\circ} \mathrm{C}$ for $48 \mathrm{~h}$. Water was freely available.

Rectal temperature was monitored and jugular blood samples were collected from day 11. A jugular vein of each steer was cannulated on day 13 and on the morning of day 14, feed was removed at $0800 \mathrm{~h}$ and at $1000 \mathrm{~h}$ blood samples $(3 \mathrm{ml})$ were collected at $15 \mathrm{~min}$ intervals for $2 \mathrm{~h}$, then LPS was injected i.v. and blood samples were collected at $15 \mathrm{~min}$ intervals for $6 \mathrm{~h}$. Intravenous glucose tolerance tests (IVGTTs) were carried out at 6 and at $24 \mathrm{~h}$ after injection of LPS to assess glucose tolerance during hypoglycemia and during recovery from endotoxemia. Glucose (50\% Dextrose Injection, Baxter Healthcare, Deerfield, IL, USA) was injected i.v. into all steers $(100 \mathrm{mg} / \mathrm{kg} \mathrm{BW})$ immediately after the $8 \mathrm{~h}$ sample was collected and blood samples were collected for a further hour at 5, 10, 15, 30, 45 and $60 \mathrm{~min}$. This protocol was repeated $24 \mathrm{~h}$ later with three blood samples collected at 15 min intervals before i.v. injection of glucose. Blood was collected into tubes containing EDTA $(7.5 \mathrm{mg})$ and kept on ice before centrifugation within $15 \mathrm{~min}$ of collection. One aliquot of harvested plasma was stored at $-20^{\circ} \mathrm{C}$ and a second aliquot was stored at $-70{ }^{\circ} \mathrm{C}$ for assaying non-esterified fatty acids (NEFA). For behavioral indications of stress, the duration of three pre-determined factors (panting; coughing or grunting; and saliva drool) were recorded at $15 \mathrm{~min}$ intervals for $7 \mathrm{~h}$ following injection of LPS.

Studies were done from February to May and all experimental procedures were approved by the Institutional Animal Care and Use Committee at Auburn University.

\section{Hormone and metabolite assays}

Insulin was assayed using a commercial RIA kit (Diagnostic Products Corporation, Los Angeles, CA, USA). Parallelism was demonstrated, curve displacement averaged $92.8 \%$ over five different concentrations, spiked recovery averaged $99.4 \%$ over four different concentrations, and the sensitivity was $15.8 \mathrm{pmol} / 1$. Intra- and interassay coefficients of variation $(\mathrm{CVs})$ were 3.7 and $3 \cdot 3 \%$ respectively. Cortisol was assayed in a modified kit from Diagnostic Products Corporation using hydrocortisone (Sigma) as standard, which was prepared in charcoal-stripped steer plasma as previously described (Sartin et al. 1988b). Standard curve concentrations ranged 
from 0.78 to $100 \mathrm{ng} / \mathrm{ml}$. Intra- and interassay CVs were $4 \cdot 3$ and $17 \cdot 2 \%$ respectively.

GH was assayed as previously described (Sartin et al. 1985). Intra- and interassay CVs were $9 \cdot 5$ and $14 \cdot 1 \%$ respectively. IGF-I was assayed in one assay as previously described (Elsasser et al. 1988). The intra-assay CV was $9 \cdot 8 \%$. TNF $\alpha$ was assayed in one assay as previously described (Kennison et al. 1990). The intra-assay CV was $8 \cdot 7 \%$. Glucose, blood urea nitrogen (BUN) and NEFA were assayed in modified colorimetric kits (glucose and BUN from Sigma and NEFA from Wako Chemicals, Richmond, VA, USA). Briefly, samples were diluted (1:20 (glucose and BUN) or 1:2 (NEFA)), assayed in duplicate and read in a spectrophotometer, at wavelengths specified by the manufacturers, against a linear standard curve (range 6.26-400 mg/dl (glucose); $2 \cdot 34-150 \mathrm{mg} / \mathrm{dl}$ (BUN); and 0.0156-1.97 mEq/1 (NEFA)) in 96-well ELISA plates. Intra- and interassay CVs were 5.7 and $3.4 \%$ respectively for glucose, 1.8 and $3 \cdot 3 \%$ respectively for BUN and 8.6 and $13.9 \%$ respectively for NEFA.

\section{Statistical analysis}

Pulse secretion parameters of GH (mean, smoothed mean, peak amplitude, peak interval and inter-peak interval) were determined from 0 to $8 \mathrm{~h}$ using the Pulsar pulse detection algorithm (Merriam \& Wachter 1982). We have previously described detection criteria for Pulsar (Sartin et al. 1988b). Glucose half-life $\left(t_{1 / 2}\right)$ was determined from log-transformed glucose decay curves from 0 to $45 \mathrm{~min}$ (Gibaldi \& Perrier 1982). Total area under the insulin curve was calculated from 0 to 45 min using the trapezoid method, then baseline was calculated as the area of the rectangle projected from 0 to $45 \mathrm{~min}$ and deducted from the total area to give a net area under the curve (insulin AUC). Similarly, net AUCs for glucose and GH were calculated from 0-150 min and 120-180 min respectively.

Data were subjected to ANOVA using the generalized linear models procedure in SAS (1990). Data for pulse secretion parameters of $\mathrm{GH}$, insulin AUC, glucose AUC, GH AUC and $t_{1 / 2}$ for glucose were analyzed as a $2 \times 2$ factorial arrangement of treatments with $\mathrm{E}_{2} / \mathrm{P}_{4}$ implant or no implant and LPS or saline as factors. In addition, data for DMI, NEFA, BUN, GH, glucose, insulin, TNF $\alpha$, cortisol and body temperature were subjected to repeat measures ANOVA with the factors detailed above. When treatments were significant, least-squares means were compared using $t$-tests.

\section{Results}

Feed intake was reduced on day $0(P<0 \cdot 001)$ and day 1 $(P<0 \cdot 01)$ in LPS-treated compared with non-LPS-treated groups (Fig. 1). In addition, S/E-treated steers ate more $(P<0 \cdot 01)$ than $\mathrm{C} / \mathrm{E}-$ treated steers on day 0.

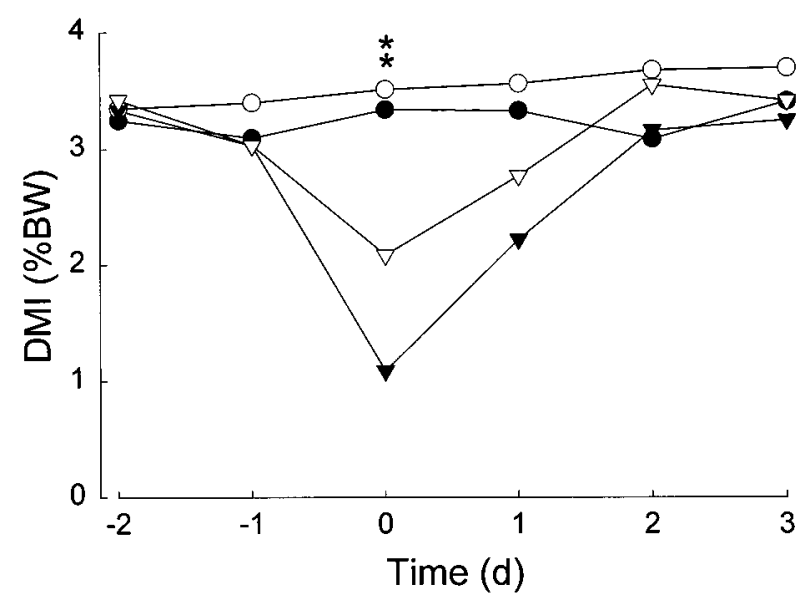

Figure 1 Least squares mean DMI expressed as a percentage of BW 2 days before and 3 days after i.v. injection of vehicle or LPS $(1 \mu \mathrm{g} / \mathrm{kg} \mathrm{BW})$ on day 0 . Treatments were: non-steroid-treated controls $(\mathrm{C} / \mathrm{C}, \mathbf{O})$; steroid-treated controls $(\mathrm{S} / \mathrm{C}, \bigcirc)$; non-steroid treated and injected with LPS $(C / E, \nabla)$; and steroid treated and injected with LPS $(S / E, \nabla)$. Asterisks denote a difference between $\mathrm{S} / \mathrm{E}$ and $\mathrm{C} / \mathrm{E}$ group means at day $0\left({ }^{* *} P<0 \cdot 01\right)$. Pooled S.E.M. $=0 \cdot 3$.

Concentrations of glucose were higher $(P<0 \cdot 001)$ in LPS-treated compared with non-LPS-treated groups from 0 to $150 \mathrm{~min}$ after i.v. injection of vehicle or LPS (Fig. 2). However, the glucose AUC was lower $(P<0 \cdot 01)$ in S/E-treated steers $\left(218\right.$ mmol.min $\left.1^{-1}\right)$ than C/E-treated steers $\left(668 \mathrm{mmol} \cdot \mathrm{min}^{-1} \mathrm{l}^{-1}\right.$ ) during this period (pooled S.E.M. $=90)$. Mean concentrations of glucose declined in plasma of LPS-treated compared with non-LPS-treated after $180 \mathrm{~min}$ and remained lower $(P<0 \cdot 001)$ from 240 to $360 \mathrm{~min}$.

Concentrations of insulin were not significantly different between groups before i.v. injection of vehicle or LPS (Fig. 2), but at $30 \mathrm{~min}$ concentrations of insulin were lower $(P<0 \cdot 001)$ in LPS-treated $(46 \cdot 5 \mathrm{pmol} / \mathrm{l})$ compared with non-LPS-treated $(124.5 \mathrm{pmol} / \mathrm{l})$ steers (pooled S.E.M. $=12 \cdot 6)$ and remained lower at $60 \mathrm{~min}(P<0 \cdot 05)$. After $60 \mathrm{~min}$, concentrations of insulin increased $(P<0 \cdot 001)$ in plasma of LPS-treated compared with nonLPS-treated steers and the insulin AUC from 60 to 300 min was not significantly different between C/E- and S/E-treated steers (Fig. 2).

Glucose $t_{1 / 2}$ was shorter $(P<0 \cdot 05)$ in LPS-treated compared with non-LPS-treated steers at the $6 \mathrm{~h}$ IVGTT, but was not significantly different between groups at the $24 \mathrm{~h}$ IVGTT (Table 1). Steroid treatment did not significantly affect glucose $t_{1 / 2}$ at either 6 or $24 \mathrm{~h}$ and there were no significant interactions between LPS and steroid treatments.

Concentrations of insulin were not significantly different between groups before IVGTT at $6 \mathrm{~h}$. However, concentrations of insulin were higher $(P<0.05)$ in S/Etreated steers than other treatment groups before IVGTT 

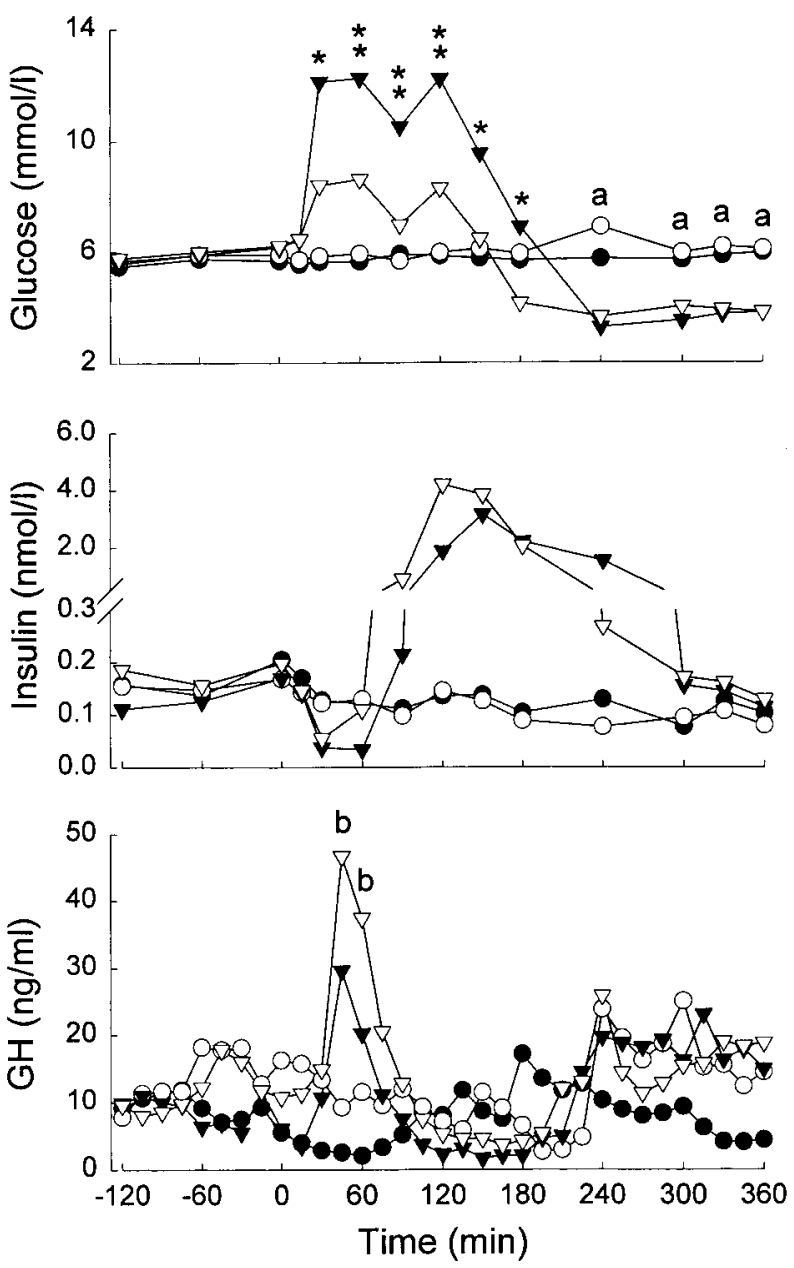

Figure 2 Least squares mean concentrations of glucose, insulin and $\mathrm{GH}$ in plasma $120 \mathrm{~min}$ before and for $360 \mathrm{~min}$ after i.v. injection of vehicle or LPS $(1 \mu \mathrm{g} / \mathrm{kg} \mathrm{BW})$ at 0 min. Treatments were: non-steroid-treated controls $(\mathrm{C} / \mathrm{C}, \mathbf{O})$; steroid-treated controls $(\mathrm{S} / \mathrm{C}, \mathrm{O})$; non-steroid treated and injected with $\mathrm{LPS}(\mathrm{C} / \mathrm{E}$ $\nabla)$; and steroid treated and injected with LPS $(\mathrm{S} / \mathrm{E}, \nabla)$. Asterisks denote differences between $\mathrm{S} / \mathrm{E}$ and $\mathrm{C} / \mathrm{E}$ group means $\left({ }^{\star} P<0 \cdot 05\right.$; $\left.{ }^{*} P<0 \cdot 01\right)$. Letters denote differences between LPS- and nonLPS-treated group means $\left({ }^{\mathrm{a}} P<0 \cdot 001 ;{ }^{\mathrm{b}} P<0 \cdot 1\right)$. Pooled S.E.M. were $0 \cdot 6$ for glucose, $0 \cdot 3$ for insulin and $4 \cdot 7$ for $\mathrm{GH}$.

at $24 \mathrm{~h}$. Insulin AUC after each IVGTT (6 and $24 \mathrm{~h}$ ) was greater in LPS-treated than in non-LPS-treated groups (Figs 3 and 4; Table 1). In addition, insulin AUC had declined at $24 \mathrm{~h}$ compared with $6 \mathrm{~h}$, but remained higher in LPS-treated compared with non-LPS-treated steers. Furthermore, insulin AUC was greater in S/E- than in C/E-treated steers at both $6 \mathrm{~h}$ and $24 \mathrm{~h}$ IVGTT (Table 1).

A synchronous increase $(P<0 \cdot 1)$ in concentrations of GH occurred between 30 and $90 \mathrm{~min}$ in LPS-treated compared with non-LPS-treated steers (Fig. 2). GH AUC from 120 to $180 \mathrm{~min}$ was lower $(P<0 \cdot 01)$ in LPStreated $\left(173 \mathrm{ng} \bullet \mathrm{min} \bullet \mathrm{ml}^{-1}\right)$ than non-LPS-treated groups
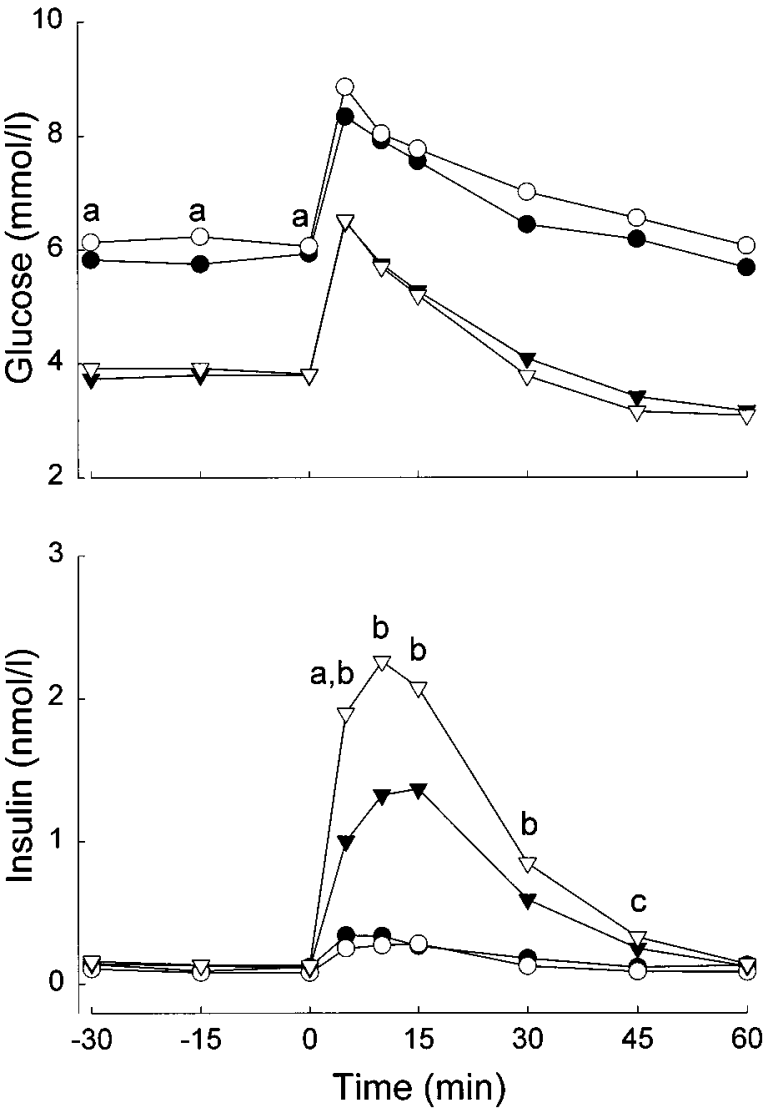

Figure 3 Least squares mean concentrations of glucose and insulin $30 \mathrm{~min}$ before and for $60 \mathrm{~min}$ after i.v. injection of glucose $(100 \mathrm{mg} / \mathrm{kg} \mathrm{BW})$ given $6 \mathrm{~h}$ after i.v. injection of vehicle or LPS $(1 \mu \mathrm{g} / \mathrm{kg} \mathrm{BW})$. Treatments were: non-steroid-treated controls $(\mathrm{C} / \mathrm{C}$ -); steroid-treated controls $(\mathrm{S} / \mathrm{C}, \mathrm{O})$; non-steroid treated and injected with LPS $(\mathrm{C} / \mathrm{E}, \boldsymbol{\nabla})$; and steroid treated and injected with LPS $(S / E, \nabla)$. Letters denote differences between LPS- and non-LPS-treated group means (glucose $={ }^{\mathrm{a}} P<0 \cdot 001$; insulin $=$ ${ }^{\mathrm{b}} P<0 \cdot 001$; $\left.{ }^{\mathrm{c}} P<0 \cdot 01\right)$. In addition, insulin concentrations for $\mathrm{S} / \mathrm{E}$ and $\mathrm{C} / \mathrm{E}$-treated steers were significantly different $5 \mathrm{~min}$ after IVGTT ( $\left.{ }^{\text {a }} P<0 \cdot 05\right)$. Pooled S.E.M. were $0 \cdot 26$ for glucose and 0.17 for insulin.

$\left(755 \mathrm{ng} \cdot \mathrm{min} \bullet \mathrm{ml}^{-1}\right) \quad$ (pooled S.E.M. $\left.=111\right)$. Regression analysis shows these reduced concentrations of $\mathrm{GH}$ to be highly related $(P<0 \cdot 001)$ to increased concentrations of insulin in LPS-treated compared with non-LPS-treated groups (equations not shown). Despite these fluctuations in concentrations of $\mathrm{GH}$, pulse secretion parameters showing mean, smoothed mean and amplitude were higher in steroid-treated than in non-steroid-treated groups (Table 2).

Concentrations of IGF-I declined in plasma of LPStreated compared with non-LPS-treated steers from day 0 until day 2 (Fig. 5). On day 3, concentrations of IGF-I were not significantly different between all groups. However, when S/E- and C/E-treated groups were considered 
Table 1 Least squares mean $t_{1 / 2}$ of glucose in plasma and mean insulin AUC at $6 \mathrm{~h}$ and $24 \mathrm{~h}$ after i.v. injection of LPS $(1 \mu \mathrm{g} / \mathrm{kg}$ BW)

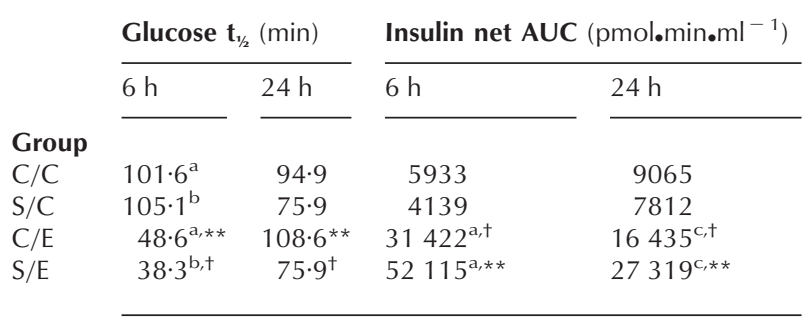

Pooled S.E.M. for glucose and insulin was $14 \cdot 2$ and 5543 respectively. Like letters within columns denote differences between treatment means: a,b $p<0 \cdot 01$.

Like symbols within rows denote differences between treatment means: ${ }^{+} P<0 \cdot 10 ;{ }^{*} P<0 \cdot 05 ;{ }^{*} P<0 \cdot 01$.

alone, concentrations of IGF-I were higher in S/E$(P<0.05)$ than in $\mathrm{C} / \mathrm{E}$-treated steers on day 3, but not different from $\mathrm{S} / \mathrm{C}$ - or $\mathrm{C} / \mathrm{C}$-treated steers $(P>0 \cdot 05)$.

Concentrations of NEFA increased in LPS-treated compared with non-LPS-treated groups at $12 \mathrm{~h}(P<0 \cdot 001)$ and remained higher than non-LPS-treated at day $1(P<0 \cdot 05)$ (Fig. 6). In addition, concentrations of NEFA were significantly lower in S/E- than in C/E-treated steers at $12 \mathrm{~h}$.

Concentrations of BUN were lower in plasma of steroid-treated compared with non-steroid-treated steers at all sample times (Fig. 6). In addition, concentrations of BUN were elevated in plasma of LPS-treated compared with non-LPS-treated steers at $12 \mathrm{~h}$ and on day 1.

Concentrations of TNF $\alpha$ increased $(P<0 \cdot 001)$ in LPStreated compared with non-LPS-treated steers $30 \mathrm{~min}$ after i.v. injection of vehicle or LPS and were maximal in plasma at $60 \mathrm{~min}$, then declined over the next $3 \mathrm{~h}$ (Fig. 7).

Body temperature increased $(P<0.05)$ in LPS-treated compared with non-LPS-treated steers after $60 \mathrm{~min}$ with a maximum observed at $240 \mathrm{~min}$, then declined over the remainder of the study (Fig. 7). Body temperature was not significantly different between LPS-treated groups.

Concentrations of cortisol increased $(P<0 \cdot 001)$ in LPStreated compared with non-LPS-treated steers after $30 \mathrm{~min}$ and remained elevated until $240 \mathrm{~min}$, then declined over the remainder of the study (Fig. 7). Concentrations of cortisol were not significantly different between LPS-treated groups.

Saliva drooled from the mouths of C/E-treated steers for $41.3 \pm 5.7 \mathrm{~min}$ and was not observed in other groups $(P<0 \cdot 01)$. In addition, duration of coughing and(or) grunting was shorter $(P<0 \cdot 01)$ in $\mathrm{S} / \mathrm{E}-(12 \mathrm{~min})$ than in C/E-treated steers $(109 \mathrm{~min})$ (pooled s.E.M. $=13)$. However, duration of panting was not significantly different between S/E- (278 $\mathrm{min}$ ) and C/E-treated steers (252 min) (pooled S.E.M. $=52$ ).
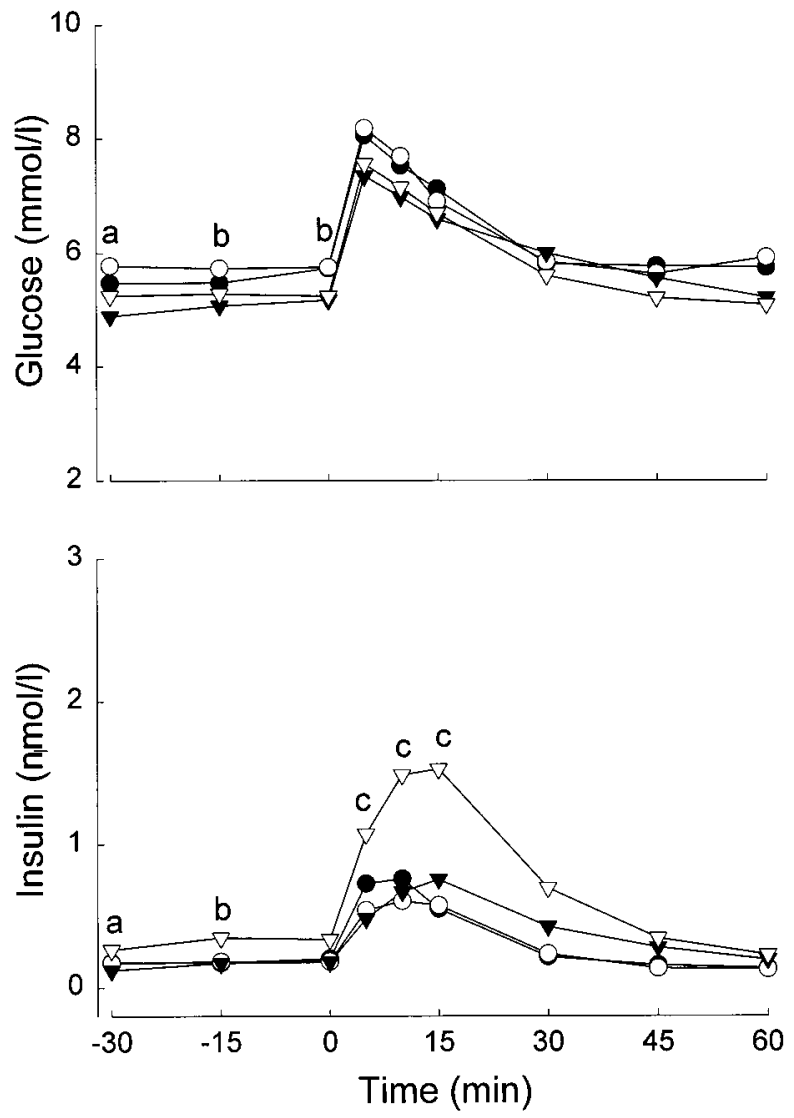

Figure 4 Least squares mean concentrations of glucose and insulin $30 \mathrm{~min}$ before and for $60 \mathrm{~min}$ following i.v. injection of glucose $(100 \mathrm{mg} / \mathrm{kg} \mathrm{BW})$ given $24 \mathrm{~h}$ after i.v. injection of vehicle or LPS $(1 \mu \mathrm{g} / \mathrm{kg} \mathrm{BW})$. Treatments were: non-steroid-treated controls $(\mathrm{C} / \mathrm{C}, \mathbf{O})$; steroid-treated controls $(\mathrm{S} / \mathrm{C}, \mathrm{O})$; non-steroid treated and injected with LPS $(\mathrm{C} / \mathrm{E}, \boldsymbol{\nabla})$; and steroid treated and injected with LPS $(S / E, \nabla)$. Letters denote differences between LPS- and non-LPS-treated group means (glucose $={ }^{\mathrm{a}} P<0 \cdot 01$; $\left.{ }^{\mathrm{b}} P<0 \cdot 05\right)$. In addition, concentrations of insulin were significantly different between $\mathrm{S} / \mathrm{E}$ and $\mathrm{C} / \mathrm{E}$ groups $\left({ }^{\mathrm{C}} \mathrm{P}<0 \cdot 05\right)$. Pooled S.E.M. were $0 \cdot 24$ for glucose and $0 \cdot 12$ for insulin.

\section{Discussion}

The results of the present study show that hyperglycemia is reduced, food intake is increased and less fat is mobilized in steers implanted with $\mathrm{E}_{2} / \mathrm{P}_{4}$ during endotoxemia. In addition, behavioral distress was reduced and concentrations of IGF-I were restored earlier in steers implanted with $\mathrm{E}_{2} / \mathrm{P}_{4}$ during endotoxemia. Furthermore, concentrations of BUN were lower in $\mathrm{E}_{2} / \mathrm{P}_{4}$-implanted steers throughout the study, indicating that protein was spared. Collectively, these data support the hypothesis that $\mathrm{E}_{2} / \mathrm{P}_{4}$ implants reduce severity of endotoxemia. However, hypoglycemia was not affected and insulin resistance increased in steers implanted with $\mathrm{E}_{2} / \mathrm{P}_{4}$ during endotoxemia. Therefore, $\mathrm{E}_{2} / \mathrm{P}_{4}$ implants do not affect all aspects of glucose homeostasis. 
Table 2 Least squares mean GH pulse parameters assessed from blood samples collected over the $8 \mathrm{~h}$ period from $2 \mathrm{~h}$ before to $6 \mathrm{~h}$ after injection of vehicle or LPS

\begin{tabular}{|c|c|c|c|c|c|}
\hline & Mean $(\mathrm{ng} / \mathrm{ml})$ & Smooth mean $(\mathrm{ng} / \mathrm{ml})$ & Amplitude (ng/ml) & Peak interval (min) & Inter-peak interval (min) \\
\hline \multicolumn{6}{|l|}{ Group } \\
\hline $\mathrm{C} / \mathrm{C}$ & $7 \cdot 37^{b}$ & $3 \cdot 21^{\mathrm{b}}$ & $5 \cdot 99^{d}$ & $44 \cdot 88$ & $64 \cdot 32$ \\
\hline $\mathrm{S} / \mathrm{C}$ & $12 \cdot 85^{\mathrm{a}}$ & $4 \cdot 48^{a}$ & $11 \cdot 55^{\mathrm{c}}$ & $36 \cdot 80$ & $57 \cdot 35$ \\
\hline$S / E$ & $12 \cdot 65^{\mathrm{a}}$ & $5 \cdot 53^{\mathrm{a}}$ & $10 \cdot 26^{c}$ & $41 \cdot 24$ & $61 \cdot 89$ \\
\hline Pooled S.E.M. & 1.95 & $0 \cdot 68$ & $2 \cdot 14$ & $4 \cdot 85$ & $5 \cdot 42$ \\
\hline
\end{tabular}

Different letters within columns denote differences within columns between treatment means: ${ }^{\mathrm{a}, \mathrm{b}} \mathrm{P}<0 \cdot 05 ;{ }^{\mathrm{c}, \mathrm{d}} \mathrm{P}<0 \cdot 01$.

Hyperglycemia develops after injection of LPS because an increased rate of gluconeogenesis and increased release of glucose from the liver, together exceed increased tissue demand for glucose (Wolfe et al. 1977, Lang et al. 1985). Uptake of glucose increases in diaphragm, fat, ileum, kidney, liver, lung, skin and spleen - tissues rich in macrophages - but not muscle (Mészáros et al. 1988, Lang \& Dobrescu 1991a,b, Lang et al. 1993). Decreased glucose requirements in skeletal muscle, but not cardiac muscle, during endotoxemia may spare glucose for increased antibacterial activity in organ tissues (Mészáros et al. 1988, Lang et al. 1993). It cannot be determined from the current study whether reduced hyperglycemia in S/Etreated steers resulted from increased glucose uptake into organ tissues, or reduced release of glucose from the liver. A study using stable isotopes to trace individual tissue uptake of glucose in endotoxic steers treated with

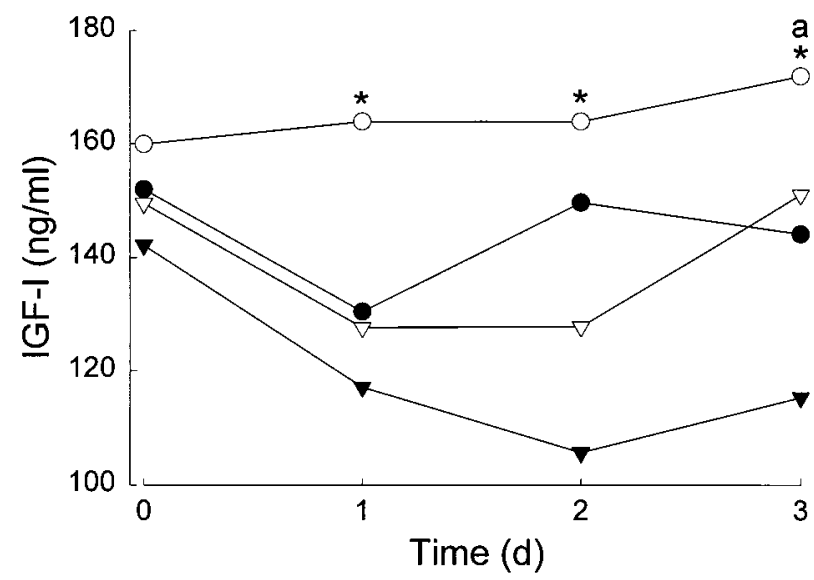

Figure 5 Least squares mean concentrations of IGF-I for 3 days after i.v. injection of vehicle or LPS $(1 \mu \mathrm{g} / \mathrm{kg} \mathrm{BW})$ on day 0 . Treatments were: non-steroid-treated controls $(\mathrm{C} / \mathrm{C}, \mathbf{Q})$; steroid-treated controls $(\mathrm{S} / \mathrm{C}, \mathrm{O})$; non-steroid treated and injected with LPS $(\mathrm{C} / \mathrm{E}, \boldsymbol{\nabla})$; and steroid treated and injected with LPS $(\mathrm{S} / \mathrm{E}$, $\nabla)$. Asterisks denote lower concentrations of IGF-I in LPS-treated groups compared with non-LPS-treated groups $\left({ }^{*} P<0 \cdot 05\right)$. In addition, concentrations of IGF-I were higher in $S / E$ than $C / E$ on day $3\left({ }^{a} P<0 \cdot 05\right)$ but not different from $\mathrm{C} / \mathrm{C}$ or $\mathrm{S} / \mathrm{C}$. Pooled S.E.M. $=10 \cdot 6$ and without gonadal steroids is needed to measure rates of glucose appearance in and disappearance from blood.

Hypoglycemia develops after initial hyperglycemia and results from increased uptake of glucose into diaphragm, spleen, liver and lung when hepatic glycogen stores are depleted and during a reduced rate of gluconeogenesis (Lang et al. 1985, 1987, 1993). Glucose tolerance was
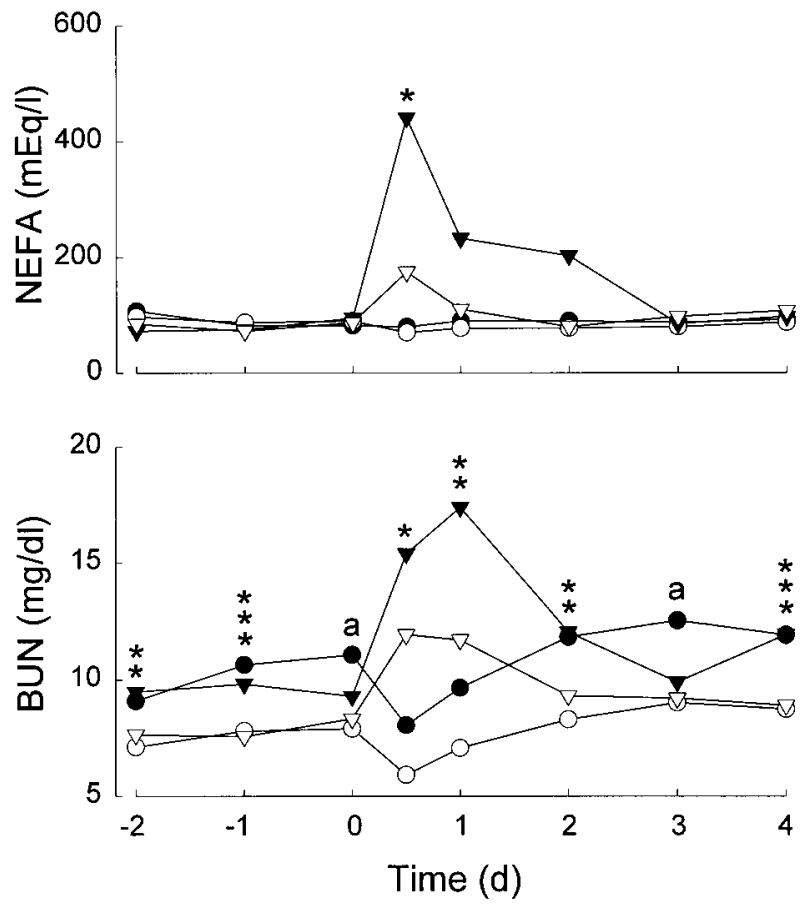

Figure 6 Least squares mean concentrations of NEFA and BUN from 2 days before to 4 days after i.v. injection of vehicle or LPS $(1 \mu \mathrm{g} / \mathrm{kg} \mathrm{BW})$ on day 0 . Treatments were: non-steroid-treated controls $(\mathrm{C} / \mathrm{C}, \mathbf{O})$; steroid-treated controls $(\mathrm{S} / \mathrm{C}, \bigcirc)$; non-steroid treated and injected with LPS $(\mathrm{C} / \mathrm{E}, \boldsymbol{\nabla})$; and steroid treated and injected with LPS $(S / E, \nabla)$. Concentrations of NEFA were significantly different $\left({ }^{*} P<0 \cdot 05\right)$ between $\mathrm{S} / \mathrm{E}$ and $\mathrm{C} / \mathrm{E}$ group means $12 \mathrm{~h}$ after injection of LPS. In addition, concentrations of BUN were lower in steroid-treated than non-steroid-treated groups

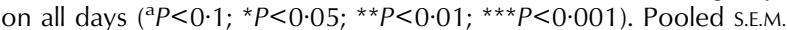
were 0.03 for NEFA and 0.9 for BUN. 

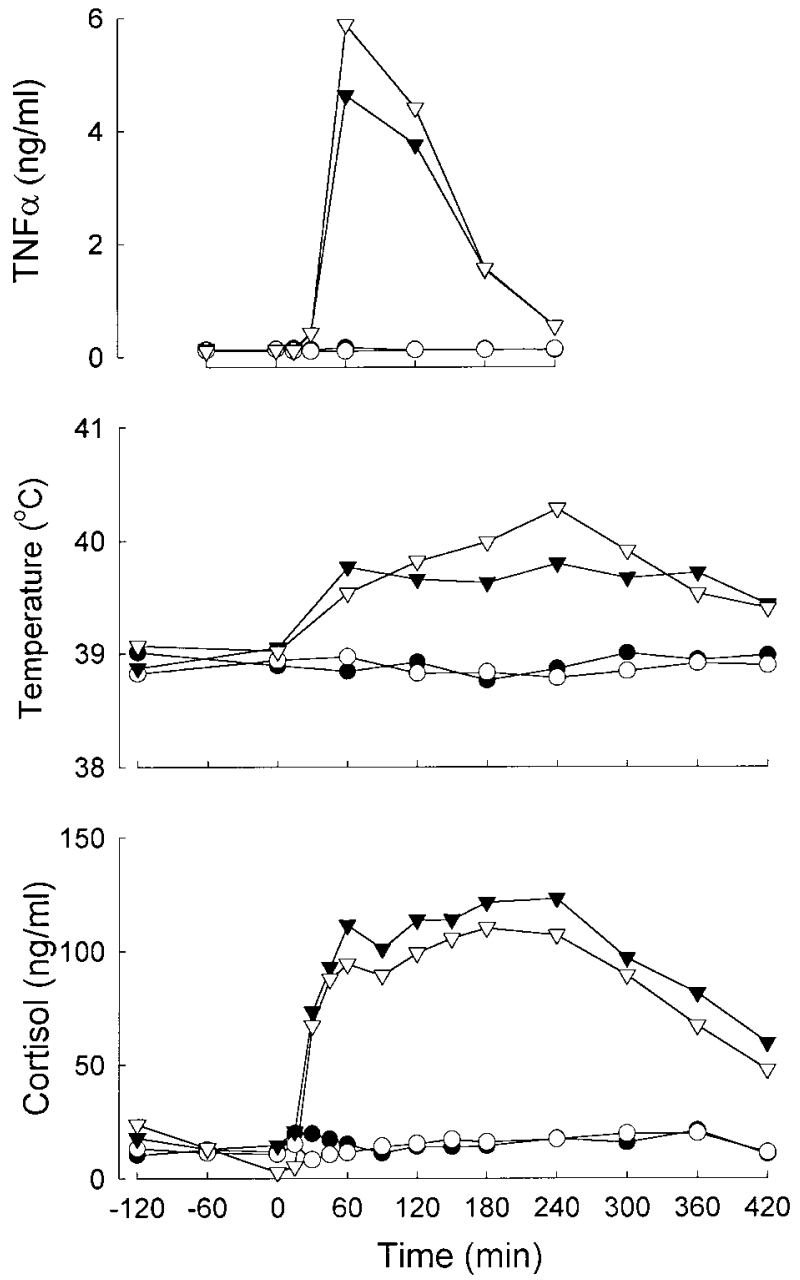

Figure 7 Least squares mean concentrations of TNF $\alpha$ from $2 \mathrm{~h}$ before to $4 \mathrm{~h}$ (TNF $\alpha$ ) or $7 \mathrm{~h}$ (cortisol and body temperature) after i.v. injection of vehicle or LPS $(1 \mu \mathrm{g} / \mathrm{kg} \mathrm{BW})$. Treatments were: non-steroid-treated controls $(\mathrm{C} / \mathrm{C}, \mathbf{O})$; steroid-treated controls $(\mathrm{S} / \mathrm{C}, \bigcirc)$; non-steroid treated and injected with LPS $(\mathrm{C} / \mathrm{E}, \boldsymbol{\nabla})$; and steroid treated and injected with LPS (S/E, $\nabla)$. Pooled S.E.M. were 0.91 for TNF $\alpha, 0.2$ for body temperature and 7.88 for cortisol.

tested at $6 \mathrm{~h}$ during early hypoglycemia and at $24 \mathrm{~h}$ when steers were recovering from hypoglycemia. It was reasoned that $\mathrm{S} / \mathrm{E}$-treated steers would recover earlier than $\mathrm{C} / \mathrm{E}$-treated steers and, therefore, would have increased energy requirements. Therefore, if LPS did not affect steers implanted with $\mathrm{E}_{2} / \mathrm{P}_{4}$ as severely as controls, glucose $\mathrm{t}_{1 / 2}$ would be shorter at 6 and $24 \mathrm{~h}$ in $\mathrm{S} / \mathrm{E}$ - compared with $\mathrm{C} / \mathrm{E}$-treated steers. However, glucose $t_{1 / 2}$ did not differ between LPS-treated groups, although it was shorter in LPS- than in non-LPS-treated groups. In addition, insulin AUC increased in LPS-compared with non-LPS-treated groups, which indicates insulin resistance. Moreover, insulin AUC was greater in S/E- than C/E-treated steers indicating greater insulin resistance in $\mathrm{S} / \mathrm{E}$-treated steers.
It is not clear why increased insulin resistance in S/Etreated steers was also associated with lessened severity of endotoxemia. However, uptake of glucose into muscle increases via non-insulin-mediated glucose uptake (NIMGU) pathways during sepsis because skeletal muscles become insulin resistant (Lang et al. 1990, Virkamäki \& Yki-Järvinen 1994). Therefore, it is possible that $\mathrm{E}_{2} / \mathrm{P}_{4}$ implants reduced both NIMGU and insulinmediated glucose uptake in skeletal muscles, which would spare more glucose for neural, cardiovascular and macrophage-rich tissues during endotoxemia.

Release of insulin from the pancreas was delayed 60 min after onset of hyperglycemia in LPS-treated steers. Moreover, concentrations of insulin were reduced from 30 to $60 \mathrm{~min}$ in LPS-treated steers, which indicates that another factor is involved in regulating release of insulin. One candidate factor is somatostatin (SS), which is synthesized in neurons in the hypothalamus (Leshin et al. 1994) and in D-cells of the pancreas and gastrointestinal tract (McIntosh 1985, Schusdziarra 1996). In rats, injections of LPS stimulate release of SS, which is probably released from the pancreas (Yelich et al. 1993, Yelich \& Witek-Janusek 1994). Those authors also observed that concentrations of insulin did not increase immediately after the onset of hyperglycemia. SS also inhibits release of insulin from $\beta$-cells (Johnson et al. 1975). Therefore, it is possible that reduced concentrations of insulin and delayed release of insulin in the present study were due to increased concentrations of SS released from the pancreas.

GH was released in a synchronized pulse between 30 and $90 \mathrm{~min}$. This pulse occurred at the same time that concentrations of insulin were reduced and concentrations of glucose were elevated in plasma. It is well established that insulin and GH are negatively related (Bassett 1972, 1974), but it is not as well understood how, or if, they regulate the release of each other. In the current study, concentrations of insulin were inversely related to concentrations of GH from 0 to $360 \mathrm{~min}$, which is consistent with insulin regulating concentrations of $\mathrm{GH}$. In contrast, concentrations of glucose were not significantly related to concentrations of GH. However, both insulin-induced hypoglycemia and i.c.v. injection of 2-deoxyglucose reduce growth hormone-releasing hormone $(\mathrm{GHRH})$ induced release of GH in sheep (Sartin et al. 1988a). Moreover, using the glucose clamp technique, Murao et al. (1994) showed that changes in concentrations of glucose, either hyper- or hypoglycemia, increase SS mRNA in the hypothalamus of rats. Furthermore, injections of insulin did not affect concentrations of GH during euglycemia in that study. An alternative explanation is that increased concentrations of NEFA suppressed concentrations of GH. Infusion of NEFA suppresses GHRH-induced release of GH (Sartin et al. 1988a) and concentrations of NEFA were elevated $12 \mathrm{~h}$ after injection of LPS in the current study. However, concentrations of NEFA were not measured at frequent intervals from 0 to 
$4 \mathrm{~h}$ to enable an appraisal of their relationship to concentrations of GH. Therefore, it is suggested that a glucoseinduced increase in synthesis of SS in the hypothalamus (Murao et al. 1994) leads to increased release of SS into hypophysial-portal vessels and inhibits release of GH from the anterior pituitary gland. However, the possibility that insulin plays a role in regulating release of $\mathrm{GH}$ cannot be excluded.

Pulsatile release of $\mathrm{GH}$ was assessed over the entire $8 \mathrm{~h}$ period, which included the $2 \mathrm{~h}$ period before and the $6 \mathrm{~h}$ period after injection of LPS. Separating the analysis into periods before and after injection of LPS was considered, but was not performed because it was reasoned that a $2 \mathrm{~h}$ period was insufficient for meaningful information on pulsatile release of $\mathrm{GH} . \mathrm{E}_{2} / \mathrm{P}_{4}$ implants increased mean concentrations of $\mathrm{GH}$ in S/E- and S/C-treated steers, despite an increased pulse of $\mathrm{GH}$ between 30 and $90 \mathrm{~min}$ and suppressed release from 120 to $180 \mathrm{~min}$ after i.v. injection of LPS. Pulse secretion parameters indicate that these increased means resulted from an increased pulse amplitude of $\mathrm{GH}$ because pulse frequency was not altered. This main treatment effect of $\mathrm{E}_{2} / \mathrm{P}_{4}$ implants on pulse amplitude of $\mathrm{GH}$ in $\mathrm{S} / \mathrm{E}$ - and $\mathrm{S} / \mathrm{C}$-treated steers is inconsistent with the marked differences in the pattern of concentrations of GH in plasma between LPS- and nonLPS-treated steers. For example, increased amplitude and mean concentrations can be attributed to the pulse between 30 and $90 \mathrm{~min}$ and increased concentrations of $\mathrm{GH}$ after $180 \mathrm{~min}$. However, given that pulse secretion parameters were also similar between $\mathrm{C} / \mathrm{E}-$ and $\mathrm{C} / \mathrm{C}-$ treated steers when a similar difference existed between their pattern of concentrations of $\mathrm{GH}$ in plasma, it is likely that $\mathrm{E}_{2} / \mathrm{P}_{4}$ implants increased $\mathrm{GH}$ amplitude. Breier et al. (1988) and Hayden et al. (1992) measured higher concentrations of $\mathrm{GH}$ in $\mathrm{E}_{2}$-treated cattle, which supports this finding.

Administration of GH and(or) IGF-I reverses catabolic states and accelerates protein gain in subjects and animals on calorie-restricted diets and during sepsis (Clemmons et al. 1992, Jurasinski \& Vary 1995, Zhao \& Donovan 1995). Furthermore, concentrations of IGF-I are higher during growth (Suttie et al. 1989) and are reduced during periods of restricted nutrition and fasting (McGuire et al. 1992, Thissen et al. 1994) and during infection and disease (Elsasser et al. 1988, 1995). Therefore, it was reasoned that calves recovering at a faster rate would have higher concentrations of IGF-I in their plasma. In the current study, concentrations of IGF-I were significantly higher in $\mathrm{S} / \mathrm{E}-$ than $\mathrm{C} / \mathrm{E}$-treated steers and not significantly different between $\mathrm{S} / \mathrm{E}$ - and $\mathrm{C} / \mathrm{C}$-treated steers on day 3, which suggests that $\mathrm{S} / \mathrm{E}$-treated steers were recovering faster from endotoxemia than $\mathrm{C} / \mathrm{E}$-treated steers.

Lungs are particularly sensitive to LPS, and respiratory distress is a common feature of endotoxemia. Activated polymorphonuclear neutrophils migrate into alveoli and septa, adhere to endothelial cells and release oxygen radicals which damage or destroy those endothelial cells (Welbourn \& Young 1992, Domenici-Lombardo et al. 1995). This generalized lung injury is associated with tachycardia, hyperventilation, hypotension, bronchoconstriction, hypoxemia and reduced lung compliance. In addition, it was noticed that sheep and cattle cough, grunt and drool saliva after injection of LPS (our unpublished observations). The duration of panting, coughing or grunting and drooled saliva was monitored for a behavioral index of steers' wellbeing. The present data show that $\mathrm{E}_{2} / \mathrm{P}_{4}$ implants abolish drooling of saliva, reduce duration of coughing and grunting, but do not alter duration of panting. It is speculated that lung injury is reduced in steers implanted with $\mathrm{E}_{2} / \mathrm{P}_{4}$. An important function of saliva is to buffer the rumen against changes in $\mathrm{pH}$ (Kay 1960). We suggest that increased secretion of saliva may reflect a mechanism to buffer the rumen against infectioninduced changes in $\mathrm{pH}$, which has been shown to occur during induced disease (Sager et al. 1990). Therefore, $\mathrm{E}_{2} / \mathrm{P}_{4}$ implants may suppress LPS-induced changes to the gastrointestinal tract.

An important observation in this study was that $\mathrm{E}_{2} / \mathrm{P}_{4}$ implants did not alter concentrations of cortisol, or reduce concentrations of TNF $\alpha$ in S/E- compared with C/Etreated steers. This suggests that reduced severity and enhanced recovery from endotoxemia in S/E- compared with $\mathrm{C} / \mathrm{E}$-treated steers cannot be attributed to immunosuppressive and anti-inflammatory actions of glucocorticoids. Nor can it be attributed to reduced concentrations of TNF $\alpha$ and(or) reduced availability of cytokine receptors. Gonadectomized male and female mice have enhanced release of adrenocorticotropin, corticosterone and TNF $\alpha$ after injection of LPS and replacement of gonadal steroids blocks these increases (Spinedi et al. 1992). Cortisol and potent analogs inhibit transcription of interleukin (IL)-1 $\beta$ (Lee et al. 1988). Moreover, cortisol blocks increased concentrations of TNF $\alpha$ and reduces concentrations of soluble TNF receptors and IL-1 receptor antagonist in a time-dependent manner in rats (Barber et al. 1993, 1995). In the present study, duration and degree of fever were not different between S/E- and $\mathrm{C} / \mathrm{E}$-treated steers. Therefore, $\mathrm{E}_{2} / \mathrm{P}_{4}$ implants act via other mechanisms to reduce severity of endotoxemia in steers.

It is concluded that $\mathrm{E}_{2} / \mathrm{P}_{4}$ implants reduce severity of endotoxemia in steers. The mechanism of action is not known, but it does not appear to act through reducing concentrations of TNF $\alpha$ or via anti-inflammatory and immunosuppressive actions associated with the hypothalamo-pituitary-adrenal axis.

\section{Acknowledgements}

We thank Dr D Pugh and the ambulatory crew at the College of Veterinary Medicine, Auburn University, for 
animal health care. We also thank $\mathrm{Dr}$ B Moss for formulating the diet fed to steers in this study, and Ms M Johnson, Mr M Pope and Mr G Fincher for animal feeding and care.

\section{References}

Barber AE, Coyle SM, Marano MA, Fischer E, Calvano SE, Fong Y, Moldawer LL \& Lowry SF 1993 Glucocorticoid therapy alters hormonal and cytokine responses to endotoxin in man. Journal of Immunology 150 1999-2006.

Barber AE, Coyle SM, Fischer E, Smith C, van der Poll T, Shires T \& Lowry SF 1995 Influence of hypercortisolemia on soluble tumor necrosis factor receptor II and interleukin-1 receptor antagonist responses to endotoxin in human beings. Surgery 118 406-411.

Bassett JM 1972 Plasma glucagon concentrations in sheep: their regulation and relation to concentrations of insulin and growth hormone. Australian Journal of Biological Science 25 1277-1287.

Bassett JM 1974 Early changes in plasma insulin and growth hormone levels after feeding in lambs and adult sheep. Australian Journal of Biological Science 27 157-166.

Breier BH, Gluckman PD \& Bass JJ 1988 Influence of nutritional status and oestradiol-17 $\beta$ on plasma growth hormone, insulin-like growth factors-I and -II and the response to exogenous growth hormone in young steers. Journal of Endocrinology 118 243-250.

Byrne TA, Morrissey TB, Gatzen C, Benfell K, Nattakom TV, Scheltinga MR, LeBoff MS, Ziegler TR \& Wilmore DW 1993 Anabolic therapy with growth hormone accelerates protein gain in surgical patients requiring nutritional rehabilitation. Annals of Surgery 218 400-418.

Clemmons DR, Smith-Banks A \& Underwood LE 1992 Reversal of diet-induced catabolism by infusion of recombinant insulin-like growth factor-I in humans. Journal of Clinical Endocrinology and Metabolism 75 234-238.

Coleman ES, Elsasser TH, Kemppainen RJ, Coleman DA \& Sartin JL 1993 Effect of endotoxin on pituitary hormone secretion in sheep. Neuroendocrinology 58 111-122.

Cryer PE 1992 Glucose homeostasis and hypoglycemia. In Williams Textbook of Endocrinology, edn 8, pp 1223-1253. Eds JD Wilson \& DW Foster. Philadelphia: WB Saunders Company.

Domenici-Lombardo L, Adembri C, Consalvo M, Forzini R, Meucci M, Romagnoli P \& Novelli GP 1995 Evolution of endotoxin induced acute lung injury in the rat. International Journal of Experimental Pathology 76 381-390.

Elsasser TH, Rumsey TS, Hammond AC \& Fayer R 1988 Influence of parasitism on plasma concentrations of growth hormone, somatomedin-C and somatomedin-binding proteins in calves. Journal of Endocrinology 116 191-200.

Elsasser TH, Fayer R, Rumsey TS \& Hartnell GF 1994 Recombinant bovine somatotropin blunts plasma tumor necrosis factor- $\alpha$, cortisol, and thromboxane- $\beta_{2}$ responses to endotoxin in vivo. Endocrinology 134 1082-1088.

Elsasser TH, Caperna TJ \& Rumsey TS 1995 Endotoxin administration decreases plasma insulin-like growth factor (IGF-I) and IGF-binding protein-2 in Angus $\times$ Hereford steers independent of changes in nutritional intake. Journal of Endocrinology 144 109-117.

Elsasser TH, Richards M, Collier R \& Hartnell GF 1996 Physiological responses to repeated endotoxin challenge are selectively affected by recombinant bovine somatotropin administration to calves. Domestic Animal Endocrinology 13 91-103.

Enright WJ, Quirke JF, Gluckman PD, Breier BH, Kennedy LG, Hart IC, Roche JF, Coert A \& Allen P 1990 Effects of long-term administration of pituitary-derived bovine growth hormone and estradiol on growth in steers. Journal of Animal Science $\mathbf{6 8}$ 2345-2356.
Gibaldi M \& Perrier D 1982 Pharmacokinetics, edn 2. New York: Marcel Dekker, Inc.

Giri SN, Emau P, Cullor JS, Stabenfeldt GH, Bruss ML, Bondurant RH \& Osburn BI 1990 Effects of endotoxin infusion on circulating levels of eicosanoids, progesterone, cortisol, glucose and lactic acid, and abortion in pregnant cows. Veterinary Microbiology 21 211-231.

Grossman CJ 1984 Regulation of the immune system by sex steroids. Endocrine Reviews $\mathbf{5}$ 435-455.

Grossman CJ 1985 Interactions between the gonadal steroids and the immune system. Science 227 257-261.

Grossman CJ 1994 The role of sex steroids in immune system regulation. In Bilateral Communication Between the Endocrine and Immune Systems, pp 1-11. Ed. CJ Grossman. New York: Springer-Verlag.

Hayden JM, Bergen WG \& Merkel RA 1992 Skeletal muscle protein metabolism and serum growth hormone, insulin, and cortisol concentrations in growing steers implanted with estradiol-17 $\beta$, trenbolone acetate, or estradiol-17 $\beta$ plus trenbolone acetate. Journal of Animal Science 70 2109-2119.

Heath HL, Blagburn BL, Elsasser TH, Pugh DG, Sanders LG, Sartin EA, Steele B \& Sartin JL 1997 Hormonal modulation of the physiological responses of calves infected with Eimeria bovis. American Journal of Veterinary Research 58 891-896.

Johnson DG, Ensinck JW, Koerker D, Palmer J \& Goodner CJ 1975 Inhibition of glucagon and insulin secretion by somatostatin in the rat pancreas perfused in situ. Endocrinology 96 370-374.

Jurasinski CV \& Vary TC 1995 Insulin-like growth factor I accelerates protein synthesis in skeletal muscle during sepsis. American Journal of Physiology 269 E977-E981.

Kay RNB 1960 The rate of flow and composition of various salivary secretions in sheep and calves. Journal of Physiology 150 515-537.

Kennison DC, Elsasser TH \& Fayer R 1990 Radioimmunoassay for bovine tumor necrosis factor alpha: concentrations and circulating molecular forms. Journal of Immunoassay 11 177-198.

Lang CH \& Dobrescu C 1991a Gram-negative infection increases noninsulin-mediated glucose disposal. Endocrinology 128 645-653.

Lang CH \& Dobrescu C $1991 b$ Sepsis-induced increases in glucose uptake by macrophage-rich tissues persist during hypoglycemia. Metabolism 40 585-593.

Lang CH, Bagby GJ \& Spitzer JJ 1985 Glucose kinetics and body temperature after lethal and nonlethal doses of endotoxin. American Journal of Physiology 248 R471-R478.

Lang CH, Bagby GJ, Buday AZ \& Spitzer JJ 1987 The contribution of gluconeogenesis to glycogen repletion during glucose infusion in endotoxemia. Metabolism 36 180-187.

Lang CH, Dobrescu C \& Mészáros K 1990 Insulin-mediated glucose uptake by individual tissues during sepsis. Metabolism 39 1096-1107.

Lang CH, Spolarics Z, Ottlakan A \& Spitzer JJ 1993 Effect of high-dose endotoxin on glucose production and utilization. Metabolism 42 1351-1358.

Lee SW, Tsou AP, Chan H, Thomas J, Petire K, Eugui EM \& Alison AC 1988 Glucocorticoids selectively inhibit the transcription of the interleukin- $1 \beta$ gene and decrease the stability of interleukin-1 $\beta$ mRNA. Proceedings of the National Academy of Sciences of the USA 85 1204-1208.

Leshin LS, Barb CR, Kiser TE, Rampacek GB \& Kraeling RR 1994 Growth hormone-releasing hormone and somatostatin neurons within the porcine and bovine hypothalamus. Neuroendocrinology 59 251-264.

McGuire MA, Vicini JL, Bauman DE \& Veenhuizen JJ 1992 Insulin-like growth factors and binding proteins in ruminants and their nutritional regulation. Journal of Animal Science $\mathbf{7 0}$ 2901-2910.

McIntosh CH 1985 Gastrointestinal somatostatin: distribution, secretion and physiological significance. Life Sciences 37 2043-2058.

Merriam GR \& Wachter KW 1982 Algorithms for study of episodic hormone secretion. American Journal of Physiology 243 E310-E318. 
Mészáros K, Lang CH, Bagby GJ \& Spitzer JJ 1988 In vivo glucose utilization by individual tissues during nonlethal hypermetabolic sepsis. Federation of American Societies for Experimental Biology 2 3083-3086.

Murao K, Sato M, Mizobuchi M, Niimi M, Ishida T \& Takahara J 1994 Acute effects of hypoglycemia and hyperglycemia on hypothalamic growth hormone-releasing hormone and somatostatin gene expression in the rat. Endocrinology 134 418-423.

Sager RL, Hamar DW \& Gould DH 1990 Clinical and biochemical alterations in calves with nutritionally induced polioencephalomalacia. American Journal of Veterinary Research 51 1969-1974.

Sartin JL, Cummins KA, Kemppainen RJ, Marple DN, Rahe CH \& Williams JC 1985 Glucagon, insulin, and growth hormone responses to glucose infusion in lactating dairy cows. American Journal of Physiology 248 E108-E114.

Sartin JL, Bartol FF, Kemppainen RJ, Dieberg G, Buxton D \& Soyoola E 1988a Modulation of growth hormone-releasing factor stimulated growth hormone secretion by plasma glucose and free fatty acid concentrations in sheep. Neuroendocrinology 48 $627-633$

Sartin JL, Kemppainen RJ, Cummins KA \& Williams JC 1988 b Plasma concentrations of metabolic hormones in high and low producing dairy cows. Journal of Dairy Science 71 650-657.

SAS 1990 SAS/STAT User's Guide, version 6, edn 4. Cary, NC: SAS Institute Inc.

Schusdziarra V 1996 Somatostatin: biological actions and pathophysiology. Progress in Basic and Clinical Pharmacology 10 35-53.

Spinedi E, Suescun MO, Hadid R, Daneva T \& Gaillard RC 1992 Effects of gonadectomy and sex hormone therapy on the endotoxin-stimulated hypothalamo-pituitary-adrenal axis: evidence for a neuroendocrine-immunological sexual dimorphism. Endocrinology $1312430-2436$.
Suttie JM, Fennessy PF, Corson ID, Laas FJ, Crosbie SF, Butler JH \& Gluckman PD 1989 Pulsatile growth hormone, insulin-like growth factors and antler development in red deer (Cervus elaphus scoticus) stags. Journal of Endocrinology 121 351-360.

Thissen J-P, Ketelslegers J-M \& Underwood LE 1994 Nutritional regulation of the insulin-like growth factors. Endocrine Reviews $\mathbf{1 5}$ 80-101.

Unruh JA 1986 Effects of endogenous and exogenous growthpromoting compounds on carcass composition, meat quality and meat nutritional value. Journal of Animal Science 62 1441-1448.

Virkamöki A \& Yki-Jörvinen H 1994 Mechanisms of insulin resistance during acute endotoxemia. Endocrinology 134 2072-2078.

Welbourn CRB \& Young Y 1992 Endotoxin, septic shock and acute lung injury: neutrophils, macrophages and inflammatory mediators. British Journal of Surgery 79 998-1003.

Wolfe RR, Elahi D \& Spitzer JJ 1977 Glucose and lactate kinetics after endotoxin administration in dogs. American Journal of Physiology 232 E180-E185.

Yelich MR \& Witek-Janusek L 1994 Glucose, lactate, insulin, and somatostatin responses to endotoxin in developing rats. Shock 2 438-444.

Yelich MR, Umporowicz DM \& Drolet BA 1993 Role of somatostatin in glucose regulation during endotoxicosis in the rat. American Journal of Physiology 264 R254-R261.

Zhao X \& Donovan SM 1995 Combined growth hormone $(\mathrm{GH})$ and insulin-like growth factor-I (IGF-I) treatment is more effective than GH or IGF-I alone at enhancing recovery from neonatal malnutrition in rats. Journal of Nutrition 125 2773-2786.

Received 6 April 1998

Accepted 12 August 1998 